\title{
六郷扇状地における池を用いた地下水人工涵養の実験
}

\author{
肥田 登*・石川悦郎**・太田由紀子***
}

\section{Experimental Study of Basin Artificial Recharge of Ground Water in Rokugo Alluvial Fan, Northern Japan}

\author{
Noboru HIDA*, Etsuro ISHIKAWA** and Yukiko OHTA***
}

\begin{abstract}
The Rokugo alluvial fan lies around $39^{\circ} 25^{\prime} \mathrm{N}$ and $140^{\circ} 34^{\prime} \mathrm{E}$ in northern Japan. The distance between the proximal fan on $90 \mathrm{~m}$ above sea level and the distal fan on $45 \mathrm{~m}$ is about $4 \mathrm{~km}$. Artificial recharge of unconfined ground water using basin method was tested in a period from April 13 to 27, 1998. The basin was constructed on the central part of the fan, and has $1,045 \mathrm{~m}^{2}$ bottom area and $3 \mathrm{~m}$ depth. Aquifer of the fan consists mainly of gravel, of which hydraulic conductivity is in order of $10^{\circ} \sim 10^{-2} \mathrm{~cm} / \mathrm{sec}$ and specific yield is over $20 \%$.

We obtained the following results through the test. 1 . During the test period, average water supply recorded $71.2 \mathrm{\ell} / \mathrm{sec}$, and average infiltration amounted to $24.5 \mathrm{~cm} /$ hour. 2 . At one of the observation wells, $480 \mathrm{~m}$ apart from the basin, ground water level began rising two days after, and the maximum ground water level appeared 11 days after the beginning of the recharge. Difference of the ground water level for the nine days was $1.40 \mathrm{~m}$. 3 . Ground water mound was formed under the basin during the recharge test. 4. In area of west and northwest direction of the recharge basin, water table was raised due to the formation of the ground water mound. Although ground water level at the Kotohira observation well goes down usually in April, it moved almost same level during the test period. 5. Effects associated with ground water level conservation ranges to the toe of the
\end{abstract}

\section{* 秋田大学教育文化学部}

Faculty of Education and Human Studies, Akita University

** 秋田県六郷町企画課

Planning Section, Rokugo Machi, Akita Prefecture

*** 秋田大学大学院教育学研究科

Graduate Student, School of Education, Akita University 
地下水学会誌 第41巻第 1 号 $23 \sim 33$ (1999)

fan. Ground water is discharged from the belt of water springs situated on the toe.

Key Words: Artificial Recharge, Ground Water, Ground Water Mound, Water Table, Alluvial Fan

\section{要 旨}

六郷扇状地は、 $39^{\circ} 25^{\prime} \mathrm{N} 、 140^{\circ} 34^{\prime} \mathrm{E}$ の周辺にある。標高 $90 \mathrm{~m}$ の扇頂と標高 $45 \mathrm{~m}$ の扇端と の間は約 $4 \mathrm{~km} ゙$ あるここで池を用いた地下水人工涵養の実験を実施した。期間は、 1998年 4 月13日から 4 月27日までの14日間である。涵養池は扇央に設置した。池底の面積

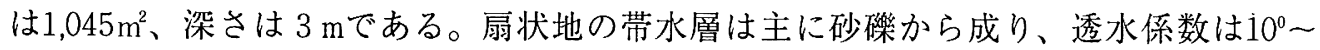
$10^{-2} \mathrm{~cm} / \mathrm{sec}$ のオーダにあり、比産出率は20\%強である。

本実験の結果、つぎの点が明らかにされた。1 、涵養期間中の池への平均給水量は、 $71.2 \ell /$ 秒、この間の池底からの平均浸透速度は、 $24.5 \mathrm{~cm} /$ 時であった。 2 . 涵養池から $480 \mathrm{~m}$ 下流の観測井では、給水を開始後 2 日めより地下水位は上昇を始め、同 11 日めに最 高水位を記録した。この間の水位の上昇高は、1.40mであった。3．涵養を実施している 間、涵養池の下部には地下水堆が形成された。4. 地下水堆の形成により、涵養池の西一 北西方向の一帯において、地下水面は上昇した。扇端にある琴平観測井の 4 月の地下水位 は、平年的には低下するが、人工涵養を実施することによって一定の高さを推移した。 5 . 人工涵養により地下水位の保全を図れる範囲は、扇端の湧泉帯までである。地下水は、こ の湧泉帯から流出する。

キーワード：人工涵養、地下水、地下水堆、地下水面、扇状地

\section{1.はしがき}

地下水人工涵養は、地下水位の低下の防止ある いは污水の浄化など、いわゆる地下水の強化・保 全策として有効に機能する (BMI, 1985; O'Hare, et al., 1986; 建設省、1988; Schmidt, 1994; 肥 田、1994; 栗城、1997)。わが国においてもその 有効性はすでに指摘され (山本、1958)、実施例は 決して多いとはいえないが、いくつかの研究成果 は報告されている(長瀬、1982; 全地対、1985; Hiyama, et al., 1989)。筆者ら も秋田県六郷扇状 地に拀いて地下水人工涵養の研究に従事してお り、小論はその成果の一端である。

六郷扇状地の不圧地下水 (以下、地下水と記す) の水位は一定の年変化をくり返す。高水位は、水
田のかんがい期間中と融雪期に現れ、低水位は、 非かんがい期に現れる。年間を通して水位が最も 低下するのは、冬季間にあって積雪の深さがピー クに達する 1 月中旬から 2 月中旬にかけてであ り、これに次いで、扇状地上の融雪が終了する 4 月上旬とかんがいによって水位が上昇に転化する 5 月上旬との間で水位は一時的に低下する(肥 田、1990、p.112)。

六郷町の市街地は六郷扇状地の扇端に位置し、 ここに住む約7,000の人びとは各々の世帯ごとに 自家用の井戸を掘り、地下水を生活用水源に当て ている。市街地の人びとにとっては、上記の、年 間を通して現れる 2 回の低水位時が凌げれば、よ り安定した地下水の確保と利用が保証される。こ の観点から、六郷局状地においては地下水の強化 
を図るために、即効性が期待される地下水の人工 涵養を導入した。水位が最も低下する積雪時にお ける人工涵養はすでに試みた(Hida, 1989; 肥 田、1997)。

今回は、融雪の終了後に現れる一時的な地下水 位の低下時に焦点を絞り、この間の地下水面の上 昇ないしは低下防止を意図して、池を用いた地下 水人工涵養の実験を実施した。涵養開始から終了 までの実験の期間は、1998年 4 月13日 (14:00)か ら 4 月27日 (14:00)までの14日間である。

実験の目的は次の点にある。第 1 に、涵養池から の浸透量を測る。第 2 に、人工涵養により地下水堆 がどのように形成されるのか、また、地下水面を上 昇させる範囲、さらに上昇にまでは及ばないにせ よ、地下水面の低下を防ぐことのできる範囲はど のように広がるのかを明らかにする。後者につい ては、人工涵養の実施期間中および実施前後の地 下水面の変動を追跡することによって確かめる。

\section{2. 六郷扇状地の水文環境}

横手盆地のほぼ中央部に位置する六郷扇状地と は、奥羽山脈から流れ出す丸子川が発達させた完 新世の複合扇状地であり、更新世の古期扇状地の 上に発達した新期扇状地を指す。東側の扇頂から 西側の扇端に向かって開く、東西約 $4 \mathrm{~km}$ 、南北 約 $5.5 \mathrm{~km}$ の半円錐形の形状は典型的な扇形を呈し ている。標高は、扇頂で約 $90 \mathrm{~m}$ 、扇端で45〜 $50 \mathrm{~m}$ 、 扇央部で $65 \mathrm{~m}$ 付近である。扇状地の中央は、北緯 $39^{\circ} 25^{\prime}$ 、東経 $140^{\circ} 34^{\prime}$ の周辺にある。

新期および古期扇状地の堆積物は、主に礫〜砂 磼の層から成る。礫径は概して大きく、径20～ $30 \mathrm{~cm}$ の巨礫の混じる層が随所に現れる。粘土層 も挟まれるが、連続性は無い。ここで、古期扇状 地堆積物の下位にある鮮新世の千屋層を扇状地の 基盤とすれば、新期と古期をあわせた扇状地堆積 物の厚さは、既存のボーリング柱状図によると、 扇状地の南端で $50 \mathrm{~m}$ 、西端で $70 \mathrm{~m}$ 、東端で $107 \mathrm{~m} に$ 達する。また、上に記した扇状地の中央の位置に おいて $100 \mathrm{~m}$ 深のボーリング調査を行った。その結 果、この地点の $100 \mathrm{~m}$ の深さまでの地層は、礫〜砂 礫から成る扇状地堆積物であることが判明した。 六郷扇状地の帯水層の飽和透水係数は、10 $~$
$10^{-2} \mathrm{~cm} / \mathrm{sec}$ のオーダにある。比産出率は $20 \%$ 強で ある。

扇頂〜扇央部は地下水の涵養域、扇端部は湧泉 帯となる。扇央部で涵養された地下水が扇端部で 湧出する流れの存在は、扇央～扇端間の水理ポテ ンシャルの鉛直分布にも現れる。湧泉は大小合わ せて60余か所を数え、そのほとんどは標高45〜 $50 \mathrm{~m}$ の間にあって南北の方向に並ぶ。多くは地下 水位の高い時期に湧出する一時泉である。

地下水位は、季節によって変動するが、扇頂部 で 4 5 m 深、扇央部で 7 〜 $\mathrm{m}$ 深、扇端部で 3 〜 $4 \mathrm{~m}$ 深程度である。

涵養域に当たる扇状地面は、土地利用の点では 圧倒的に水田が多く、全面積の約70\%に達する。 年平均の降水量は $1,800 \mathrm{~mm}$ 、積雪の深さは最大で 130〜150cm である。

\section{3. 池による地下水人工涵養の実施}

\section{1 池の位置の選定}

涵養池を設営した位置は、次の理由から、扇央部 のやや北寄りの北緯 $39^{\circ} 25^{\prime} 25^{\prime \prime}$ 、東経 $140^{\circ} 34^{\prime} 08^{\prime \prime}$ 、 標高 $62 \mathrm{~m}$ に定めた。

第 1 に、扇面の涵養域の内で、地下水面の変動 幅の最も大きい扇央部に置く。扇央部の地下水面 の上昇は下方に波及して扇端部の地下水面を上昇 させることが水理ポテンシャルに関する観測によ り経験的に知られているからである(肥田、 1990、pp.167〜182)。

第 2 に、六郷局状地内の地下水は、地下水面の 高低にかかわらず一般に扇面の最大傾斜の方向に 流れている。このことから、涵養池を扇央部のや や北寄りに置くことにより、扇端・市街地の北寄 りの一帯の地下水面を上昇させること、ないしは 低下を防止することが期待される。

第 3 に、扇央部のやや北寄りの位置を選んだの は、市街地の中心部に流れこむ地下水の流線上に、 すでに別の涵養池が設営されているからである゙。

第 4 に、涵養池に供給する源水には、水田かん がいの排水路の水を当てることとした。このこと から、上の 3 点に加えて池の用地をかんがい排水 路に接する場所に選んだ。 


\section{2 涵養池の設営、構造}

涵養池の用地：六郷町が25aの水田を買い上 げ、ここに涵養池を設営した。池の造成は、1998 年 3 月下旬〜 4 月初旬に行った。

涵養池の構造：形状は図 1 に示すとおりであ る。池底の面積は $1,045 \mathrm{~m}^{2}$ 、ノリ面を含めた池の 総面積は $1,896 \mathrm{~m}^{2}$ 、池の深さは、給水口のある東 寄りで $2.8 \mathrm{~m}$ 、そのほかでは $3.0 \mathrm{~m}$ とした。池は、 底、ノリ面ともに素掘りの状態であり、扇状地の 礫〜砂礫の層が露出している(写真 1 -a)。かんが い排水路 $($ 幅 $60 \mathrm{~cm}$ 、深 $50 \mathrm{~cm})$ は池の東側にあり、 この排水路から涵養池に水を引くための取り入れ 口と用水路 (幅 $45 \mathrm{~cm}$ 、深 $30 \mathrm{~cm}$ 、長さ $9.8 \mathrm{~m}$ ) は池の 南東部にとり付けた (写真 1 -b)。

地質：涵養池を設営した位置の地層は、典型的 な扇状地の完新世堆積物である。水田の表土は $20 \mathrm{~cm}$ 、それ以深 $3.0 \mathrm{~m}$ の深さまでは、主として磁 層から成る。礫径は、平均して10 $12 \mathrm{~cm}$ 、大き いもので $25 \mathrm{~cm}$ 程である。深さ $3.0 \mathrm{~m}$ までの間に粘 土層は現れない。

人工涵養に使う源水：源水として使うかんがい
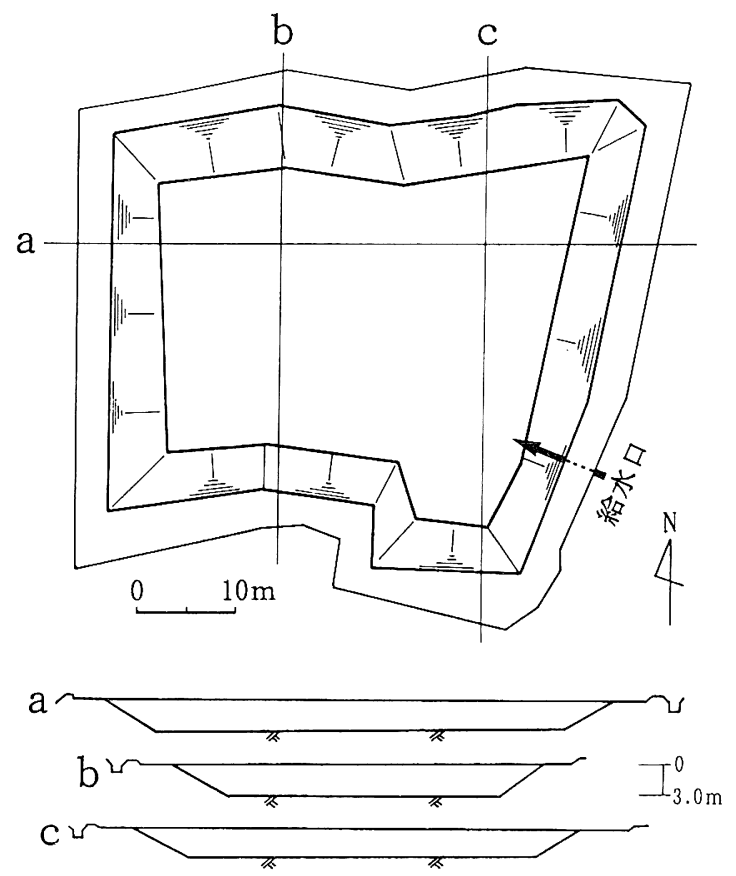

図 1 涵養池の構造、1998年 4 月

Fig. 1 Structure of artificial recharge basin, April, 1998

(注：池の位置は図 4-1～2 参照。)
排水路の水は、六郷扇状地の扇頂で取得される丸 子川の水であり、年間を通して流れている。排水路 の水は前処理を施さずに涵養池に直接流しこむ2)。

\section{3 観測}

給水量の測定：涵養池への給水量は、かんがい 排水路から涵養池に水を引くために、池の南東部 にとり付けた用水路の位置で測定した。流速の測 定にはプライス流速計を用いた。観測は、1日 3 回、6:00、12:00、18:00に実施した。

地下水位の観測：地下水面の変動を追跡するた めに、地下水位の観測を行った。観測には、自記 水位計付きの観測井 (扇端部の琴平、米町、上町 の 3 地点にある) と扇央一扇端部に設置されてい る17地点の測水用の観測井を用いた。このほか、 涵養池の西方の一帯において、6 地点の既設の井 戸を測水用に加えた。観測地点の位置は図 4-1 〜2に示した。

観測井は、内径 $65 \mathrm{~mm}$ の鉄パイプ製であり (写真 1 -c)、 $5 \mathrm{~m}$ より浅い井戸には先端に $50 \mathrm{~cm} 、 5 \mathrm{~m}$ を超える井戸には先端に $100 \mathrm{~cm}$ のスクリーンを付 けてある。観測井、既設井とも、井戸の天端の標 高は、水準測量により測定した。

人工涵養にともなう地下水面の変動を追跡する に当たり、使用した観測井は、局央部においては $7 \sim 10 \mathrm{~m}$ 程度、扇端部においては $3 \sim 7 \mathrm{~m}$ 程度の 深度の浅いものに限った。既設井の深さもこれに 準じた。なぜならば、扇状地堆積物の浅層の不圧 帯水層の水理ポテンシャル值をもって地下水面を 連続させるためである3”。

降水量は、自記雨量計により扇央部において観 測した。

\section{4. 人工婳養の結果}

\section{1 給水量と酒養池の浸透量 (図 2)}

人工涵養を実施した期間中 (1998.4 .13、14：00 ４.27、14:00)の涵養池への給水量は、図 2 に 示すと抢りである。給水量の測定は、 $3-3$ で述 ベた方法によった。

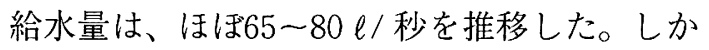
し、かんがい排水路の維持管理の都合から、排水 路に一時的に多量の水が流れ、その結果、4月19 


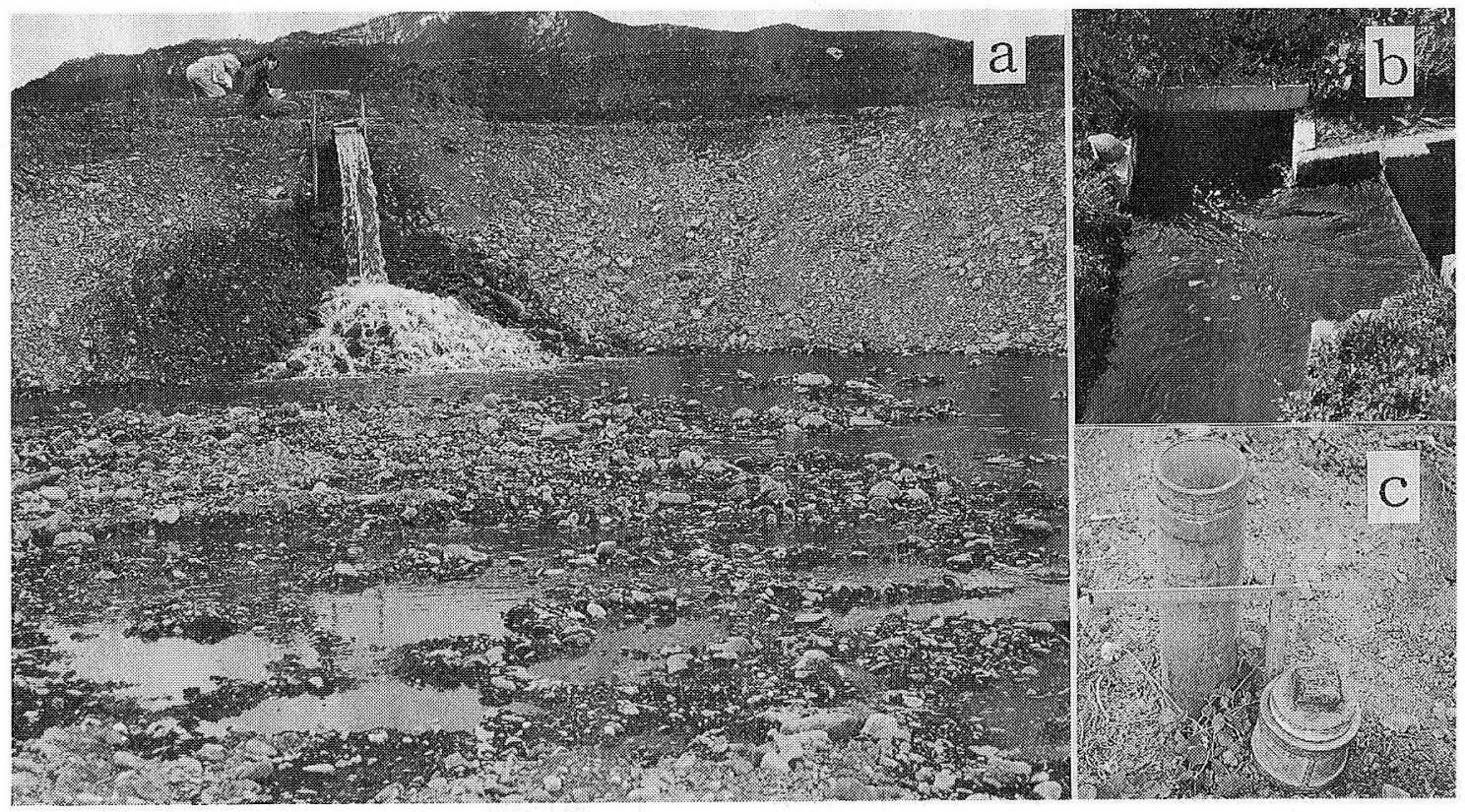

写真1-a,b,c 涵養池の内部と磁層 (a)、かんがい排水路からの取水 (b)、および測水用の観湘井 (c)、1998年 4 月

Photo 1-a,b,c Inside of the artificial recharge basin and gravel formation(a), water intake from irrigation drainage canal(b), and observation well for ground water level measurement(c), April, 1998

日、6：00と 4 月22日、18：000観測において、 給水量は $120 \ell /$ 秒台に達した。逆に、24日以降の 給水量にはバラッキが生じ、4 月25日の給水量は 一時的にゼロとなった。これは、農家が代かきな どの準備のために用排水路の管理に手を加え始 め、排水路の流量に変動を来すようになったため である。

涵養期間中の池への平均給水量は、44回の観測

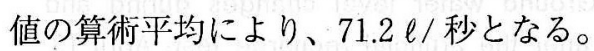

給水を開始して 4 日め、4月17日、18：00頃か ら西側一带の池底に湛水が始まった。以降、一時 的に池底の全面に湛水の状態が現れたが、給水を 停止する時点まで、湛水の状態が継続したのは、

底全体のおおよそ $1 / 2$ 程度の西側の範囲に限られた。

いま、 $71.2 \ell /$ 秒の水が、面積 $1,045 \mathrm{~m}^{2}$ の池底か ら一様に浸透したとすれば、涵養期間中の池底か らの平均浸透速度は、 $24.5 \mathrm{~cm} /$ 時となる。湛水が 始まる以前の浸透速度は、言うまでもなくこの值 よりも大きい。上の值は、これまでに行った六郷 扇状地における浸透実験の結果に照らしても順当 な值である(肥田、1987)。

\section{2 地下水位の変動}

人工涵養の実施期間中および終了 5 日後までの 地下水位はどのように変動したのか、涵養池の位 置から西方に開く一帯から 4 地点の観測井の記録 を選び図 3 に例示した。 4 地点の観測井には 2 か ら 5 までの番号を付し、所在地を図 4-1 - 2 に 示した。婳養池に比較的近い位置の例として 2 と 3 を採り、市街地の中央部に比較的近い位置の例 として 4 と 5 を採った。涵養池に最も近い観測井 1 については、井戸の深度が浅く地下水位の変動 が連続して記録されなかったので、図 3 には示さ なかった。また、終了5 日後までとしたのは、そ の後の 5 月 6 日ころから、水田かんがいの影響に よる地下水位の上昇の兆候が所により現れるよう になったからである。

観測井 $2\left(39^{\circ} 25^{\prime} 26^{\prime \prime} \mathrm{N} 、 140^{\circ} 33^{\prime} 55^{\prime \prime} \mathrm{E}\right.$ 、天端標 高61.66m、深さ $15.40 \mathrm{~m}) ： 1998$ 年の場合、六郷扇 状地の融雪末期における地下水位のピークは 3 月 23日前後に現れ、それ以降の水位は一貫して低下 した(図 6 参照)。給水を開始する以前の測水によ ると、観測井 2 の地下水位 (標高) は、4 月 1 日 $(51.41 \mathrm{~m}) 、 4$ 月 10 日 $(50.44 \mathrm{~m}) 、 4$ 月 13 日、18:00 


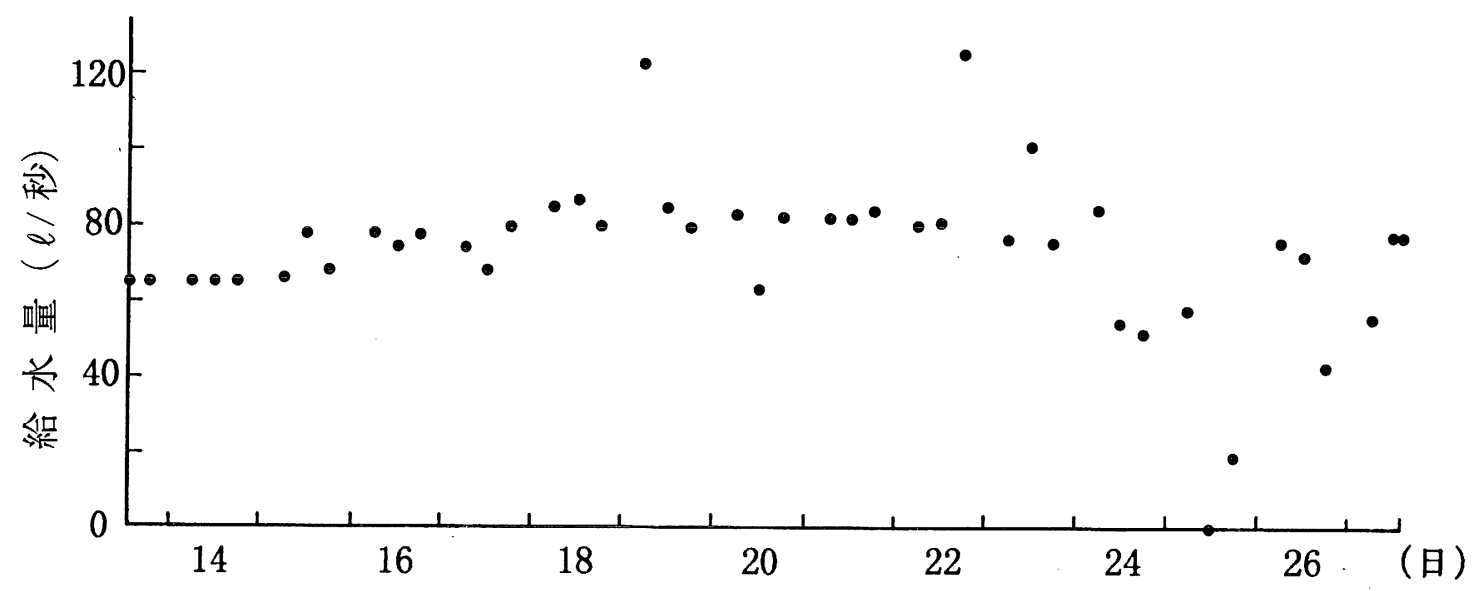

図 2 婳盖池への給水量、1998年 4 月13日 (14:00) 4 月27日 $(14: 00)$

Fig. 2 Water supply to the artificial recharge basin, April $13(14: 00) \sim$ April $27(14: 00), 1998$ （注：黒丸は、測定時点の給水量を示す。）

(50.28m) と低下した。これに対して、給水を開始 した翌日 4 月14日、6:00の記録 $(50.31 \mathrm{~m})$ から水 位は上昇に転じた。最高水位は、4月24日、6：00 に現れ、 $51.15 \mathrm{~m}$ に達した。この間、人工涵養に よる水位の上昇高は $0.87 \mathrm{~m}$ であった。 4 月 $24 \sim 25$ 日の給水量の一時的な減少(図 2)により、水位は やや下がった。さらに、給水を停止した 4 月27日 以降は、水位は低下を続け、5月 2 日、18：00に は、 $50.38 \mathrm{~m}$ にまで下がった。

観測井 2 における水位の上昇と下降の変動カー ブは、次に記す観測井 3 の変動カーブに比べて緩 慢である。観測井 2 の方が観測井 3 よりも涵養池 に近い位置にあるにもかかわらず、このような違 いを呈した理由はかならずしも明確にはできな い。考えられることは、観測井 2 には未使用の既 設井をもって当てたので、スクリーンの劣化がす でに進んでいたのか、あるいは、この井戸は観測 井 3 に比べて $6 \mathrm{~m}$ ほど深いこと、そして両者とも 最先端にスクリーンをとり付けているので、深さ の違いによる圧力水頭の違いが現れたことも推測 される4)。

上のような点を考慮し、図 4-1〜2 の地下水 面図を作成する際には、深度の浅い観測井から得 られた測水の結果のみを採用しており、観測井 2 の記録は使用していない。

観測井 $3\left(39^{\circ} 25^{\prime} 36^{\prime \prime} \mathrm{N} 、 140^{\circ} 33^{\prime} 48^{\prime \prime} \mathrm{E}\right.$ 、天端標 高 $58.54 \mathrm{~m}$ 、深さ $9.51 \mathrm{~m})$ : 地下水位が降下寸る過程

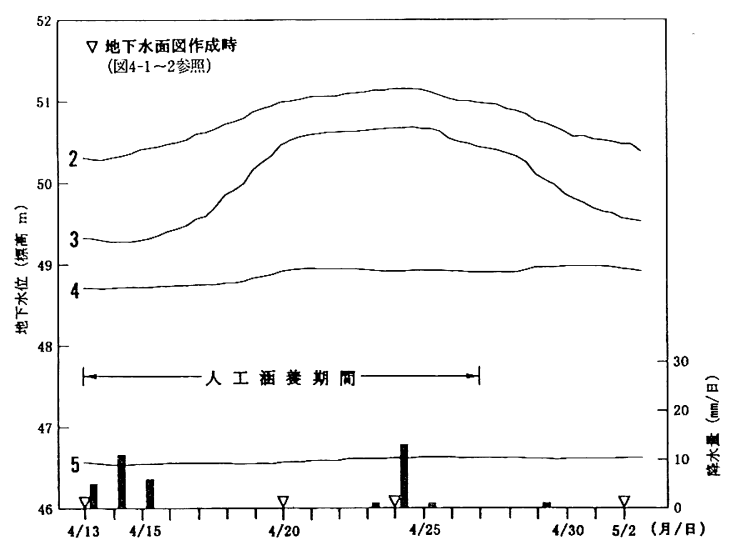

図 3 人工婳養の実施期間中および终了後の地下水 位の変動、1998年 4 月13日〜 5 月 2 日

Fig. 3 Ground water level changes during and after the artificial recharge test, April 13, 〜 May 2, 1998

(注：降水量は、扇央部で測定。位置は図 $4-1 \sim 2$ 参照。)

にあって、観測井 3 の水位が上昇に転じたのは、 給水を開始して 2 日を経た 4 月15日からである。 4 月14日、18：00の水位 $49.28 \mathrm{~m}$ は、 4 月24日、 18：00に、最高水位の $50.68 \mathrm{~m}$ にまで達した。こ の間の水位の上昇高は、 $1.40 \mathrm{~m}$ である。4 月24 25日の給水量の減少は、4月25日、18：00の記録 から一時的な水位降下の現象となって現れる。給 水を停止した後の水位は、低下を続け 5 月 2 日、 $18 ： 00 に 49.52 \mathrm{~m}$ となった。 
観測井 $4\left(39^{\circ} 25^{\prime} 13^{\prime \prime} \mathrm{N} 、 140^{\circ} 33^{\prime} 28^{\prime \prime} \mathrm{E}\right.$ 、天端標 高 $55.89 \mathrm{~m}$ 、深さ $9.23 \mathrm{~m})$ : 涵養池の南西約 $1 \mathrm{~km}$ の 位置にある。給水を開始して 3 日を経た 4 月 16 日 頃から地下水位は、一日当たり数 $\mathrm{cm}$ ほどの上昇 を続け、4月21日、6:00に最高水位 $48.95 \mathrm{~m}$ を記 録した。給水前の水位と比べて、この時点の水位 の上昇高は $24 \mathrm{~cm}$ であった。 4 月 22 日以降の水位 は数 $\mathrm{cm}$ の動きを見る程度で推移する。4 月28日、 $12 ： 00$ から 4 月30日、6：00にかけて $5 \mathrm{~cm}$ ほどの 水位の上昇が生じたが、これは、4月28日の前後 に観測井 4 に接する水田に水が入ったことによる ものと思われる。

図 3 に示した 3 地点の観測井のほかに、さらに 観測井 1 および同 5 (図 4-1〜2参照)における 水位変動の特徵についてふれておく。

観測井 $1\left(39^{\circ} 25^{\prime} 27^{\prime \prime} \mathrm{N} 、 140^{\circ} 34^{\prime} 01^{\prime \prime} \mathrm{E}\right.$ 、天端標 高 $61.42 \mathrm{~m}$ 、媣さ $8.08 \mathrm{~m})$ : この井戸は涵養池に最も 近く、池の中心からほぼ西方 $125 \mathrm{~m}$ の位置にある。 かんがい用に設置された既設の浅井戸である。池 に給水を開始した時点の記録は採れなかったが、 開始 5 日後の 4 月18日、6:00の地下水位は53.37 $\mathrm{m} 、 4$ 月20日、12：00に最高水位 $53.77 \mathrm{~m}$ を記録し た。以降、給水量の変動を反映して水位は、 $10 \mathrm{~cm}$ ほどの変動幅を持って推移した。4月24日、 $17: 00$ の水位は $53.65 \mathrm{~m}$ となり、4月27日に給水 を停止してから 4 時間後の測水から水位は経時的 に低下した。

観測井 $5\left(39^{\circ} 25^{\prime} 28^{\prime \prime} \mathrm{N} 、 140^{\circ} 33^{\prime} 22^{\prime \prime} \mathrm{E}\right.$ 、天端標 高 $52.02 \mathrm{~m}$ 、深さ $9.60 \mathrm{~m})$ : この井戸は、涵養池の西 方にあり市街地の北部に近接する。涵養期間中に は、池からほぼ西方に流れる地下水の主要な流れ の範囲内にある(図 4-2)。涵養池への給水を開 始するまでの水位は低下過程にあったが、給水を 開始した翌日から低下現象は見られなくなり、水 位はほほ等しい高さで推移するようになった。さ らに、涵養期間の後半に入ると、水位は給水当初 よりも $8 \mathrm{~cm}$ 上昇した。観測井 5 の地点の地下水 位が、平年的には水位の低下期にありながら、上 に示すような現象を呈したのは、人工涵養によっ て形成された地下水堆(後述、図 $4-2$ および図 5 を参照)の影響を受けながら、水位の低下を防ぐ 効果を現したものである。この点は、後の 4-4 で述べる琴平観測井の水位変動の特性に類似して
いる。なお、扇端域にある観測井 5 および琴平観 測井の両地点とも、4 月の内に水田かんがいの影 響のもとで、水位の上昇を来すことはなく(太田、 1997）、扇端に分布する湧泉群の影響のもとで、 水位の降下を抑制ないし上昇させることはない (佐藤、1998)。

地下水人工涵養の実験を実施した、1998年 4 月 13日 (14：00) から 4 月27日 (14：00)までの14日間 の総降水量は、扇央部の観測の結果によると、 $37 \mathrm{~mm}$ であった。降水の時間分布は、給水を開始 した当初の 4 月13日〜15日に22mm、さらに間を おいて、給水を停止するまぎわの 4 月23日～25日 に $15 \mathrm{~mm}$ である(図 3 )。日最大の降水量は、4 月 24日の $13 \mathrm{~mm}$ であった。日量 $13 \mathrm{~mm}$ の降水は、地 表面から数mの浅い位置にある、扇端部の地下水 位の上昇に対しては若干の影響を及ぼしいるが (図6の上町)、扇央部に近い、涵養池の西方一带 の地下水位に変動を及ぼすほどのものではない。

\section{3 地下水面の变動}

地下水面図 (図 4-1 ～2 ) は、地下水人工涵養 の実験を行っている期間中およびその前後を対象 に、涵養池の西方一帯から市街地を含めた範囲に おいて 4 回の一斉測水を行い、各時点の測水の結 果に基づいて作成した。各時点の地下水面図は、 以下に示す。また、4 回のそれぞれの時点は、地 下水位の変動と照合できるように図 3 にも示し た。

図 4-1〜2の地下水面図を作成するに当た り、次の点が前提となっている。第 1 に、先の 4-2で記した理由により、測水の結果は、深度 の浅い観測井から得られた記録に限った。また、 観測井 2 の測水の結果は採用していない。

第 2 に、測水に用いた観測地点は、4 回の各時 点とも一致しているとは限らない。そのために、 地下水面図上で等ポテンシャル線の描ける範囲が 測水の時点によって異なることがある。給水を実 施している間の測水に際しては、池の近くと池の 西方一帯など、人工涵養によって水位変動が及ぶ と思われる範囲の観測地点に重点を置いた。

第 3 に、涵養池のある位置の地表面の標高は、 測量の結果、 $62.65 \mathrm{~m}$ である。人工涵養を実施し ている間の池の位置の地下水位(ここでは、地表 


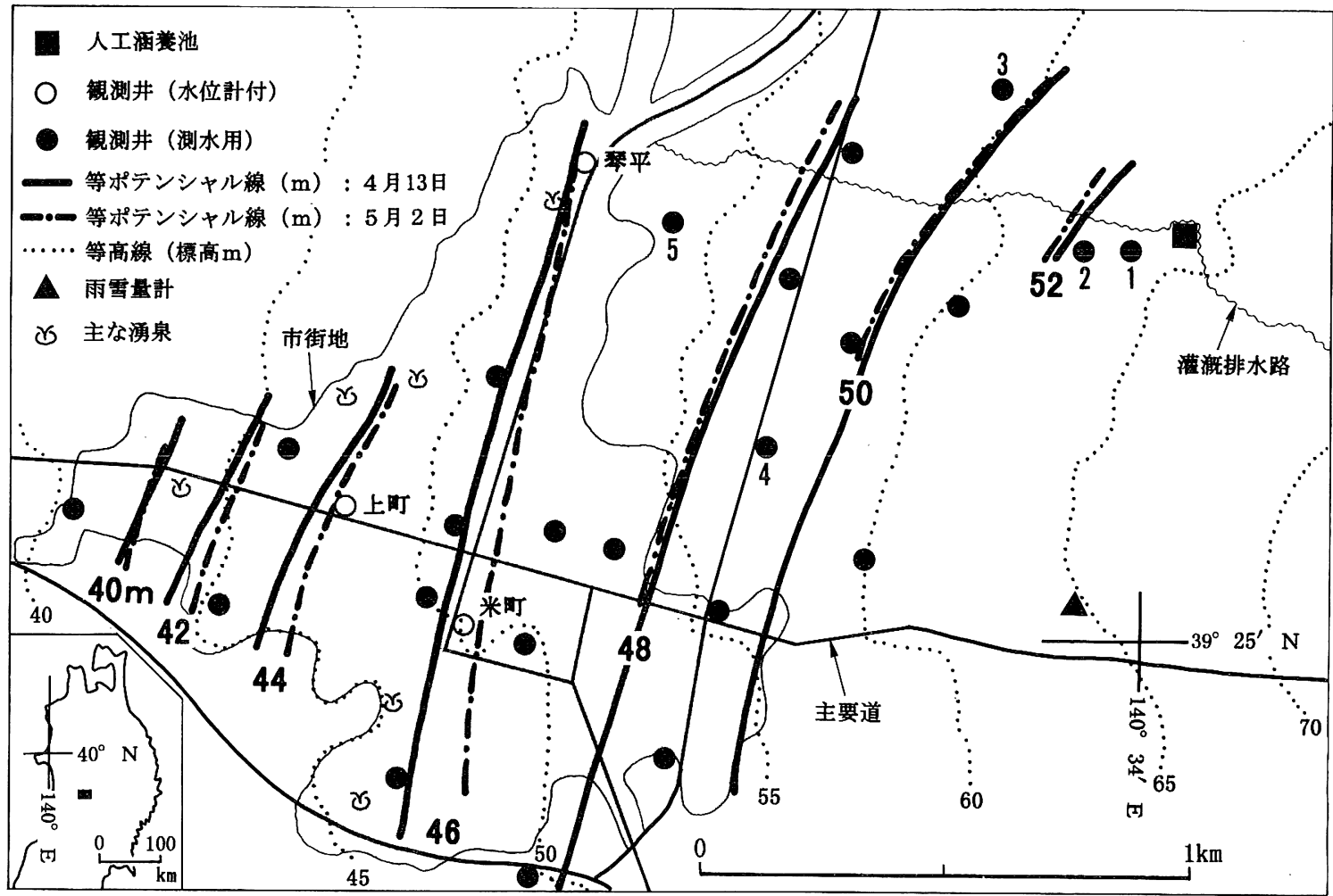

図 4-1 人工酒養の実施前後の地下水面図、1998年 4 月13日および 5 月 2 日

Fig. 4-1 Equipotential lines before and after the artificial recharge test, April 13, and May 2, 1998 （注：観測井の一斉測水に基づいて作成。）

から地下水面までの深度) は、観測井 1 の地下水 位(同)よりも深いことはあり得ない。したがって、 仮に池の位置の水位が観測井 1 の水位と等しい深 さとすれば、すでに得られている観測井 1 の天端 標高と測水の結果とから、池の位置の地下水面は、 4 月20日、12：00において、少なくても55.0m、 4 月24日、17：00において、少なくても54.88m と算定される。図 4-1〜2の作成には、これら の值を採用した。

\subsection{1 給水開始直前( 4 月13日、12:00)の地下 水面(図 4-1)}

六郷町の市街地、特に北部に流れ込む地下水は、 おおむね扇央から扇端に向かって東南東から西北 西の方向に流れる。測水を実施した範囲内におい ては、等ポテンシャル線の分布から見て、北側よ りも南側において地下水面は高い。

等ポテンシャル線で46～48m の間の動水勾配 は、北側で $4.4 \times 10^{-3}$ ほど、南側で $5.7 \times 10^{-3}$ ほどで
あり、南側でやや大きい。一方、44〜 46m 間の動 水勾配は、南側でやや小さい。

\subsection{2 給水開始 1 週間後( 4 月20日、12:00)の 地下水面 (図 4 - 2)}

涵養池の下部に円錐形に類した地下水堆が形成 される。地下水堆の頂点は、先に記したとおり、 少なくても標高 $55 \mathrm{~m}$ には達する。地下水堆が形成 される経過は、図 3 の地下水位の変動と対応する。 地下水堆の形成にともない、涵養池の西方にある $48 \mathrm{~m} 、 50 \mathrm{~m}$ の等ポテンシャル線は、給水開始直前 のそれぞれの值の位置よりも西〜北西側に張り出 した。

このほか、 $46 \mathrm{~m}$ の等ポテンシャル線の位置は、 給水開始直前に比べて、涵養池の西方にある琴平 観測井の地点においては、ほとんど動いていない が、市街地の南側においてはやや南東方向へ後退 した。この頃、市街地の南側において地下水面が 後退するのは、平年的な現象である。また、 $44 \mathrm{~m}$ 


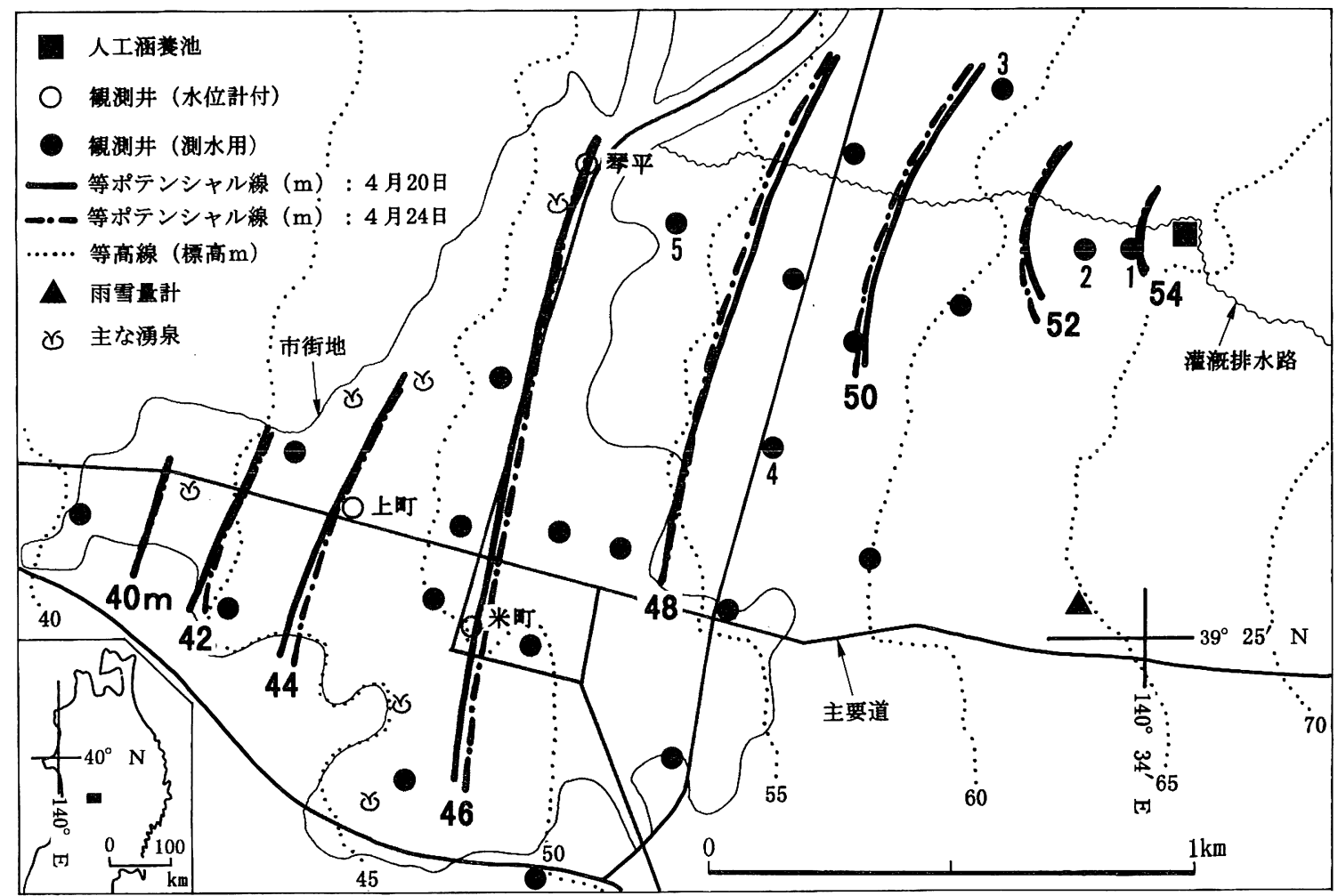

図 4- 2 人工婳養実施中の地下水面図、1998年 4 月20日および4 月24日

Fig. 4-2 Equipotential lines during the artificial recharge test, April 20, and April 24, 1998 (注：観測井の一斉測水に基ついて作成。)

よりも低い等ポテンシャル線は、湧泉帯あるいは それよりも標高の低い西側にあるため、給水開始 直前とほほ同じ位置にある。

\subsection{3 給水中の最高水位時 ( 4 月24日、12:00) の地下水面(図 4-2)}

ここに示す地下水面図は、涵養池の西方一帯の 地下水位が最も高まった時のものである。最高水 位時とは言え、涵養池の下部に形成されている地 下水堆の頂点は、4月20日よりもやや下がり、 $54 \mathrm{~m}$ 台となる。これは、24日に入ってからの池へ の給水量の減少が(図 2)、同日の地下水堆の頂点 を直ちに低下させたからである。しかし、24日以 前に形成された地下水堆が平衡状態にもどる過程 で、池の西側の $48 \mathrm{~m} 、 50 \mathrm{~m} 、 52 \mathrm{~m}$ の等ポテンシャ ル線の位置は、わずかながら、20日の各等ポテン シャル線の位置よりも西〜北西側に移動した。

さらに、 $46 \mathrm{~m}$ の等ポテンシャル線は、琴平観測 井の地点においては20日の時点と変わらないが、
市街地の南側において20日の時点よりやや東方に 後退している。東方への若干の後退は、 $42 \mathrm{~m}$ 、 $44 \mathrm{~m}$ の等ポテンシャル線にも見られる。これは平 年的な地下水位の低下によるものである。

\subsection{4 給水停止 5 日後 ( 5 月 2 日、17:00)の地 下水面(図 4-1)}

地下水面の広がりは、全般的にはほぼ給水開始 直前 (4月13日)の状態にもどった。

ただ、涵養池の北西側、 $48 \mathrm{~m} 、 50 \mathrm{~m} 、 52 \mathrm{~m}$ の 等ポテンシャル線は、給水を始める直前の位置よ りも西側にあり、人工涵養の影響が残っている。 琴平観測井の地下水面は、直前の高さにもどった。

これに対し、42m、44m、46m の等ポテンシャ ル線は、市街地の南側に移るにしたがい、給水を 始める直前の位置よりも東側に後退した。この後 退は、融雪末期からかんがい初期の間にあって、 六郷扇状地の地下水が低水位化する平年的な現象 を呈しているものである。 


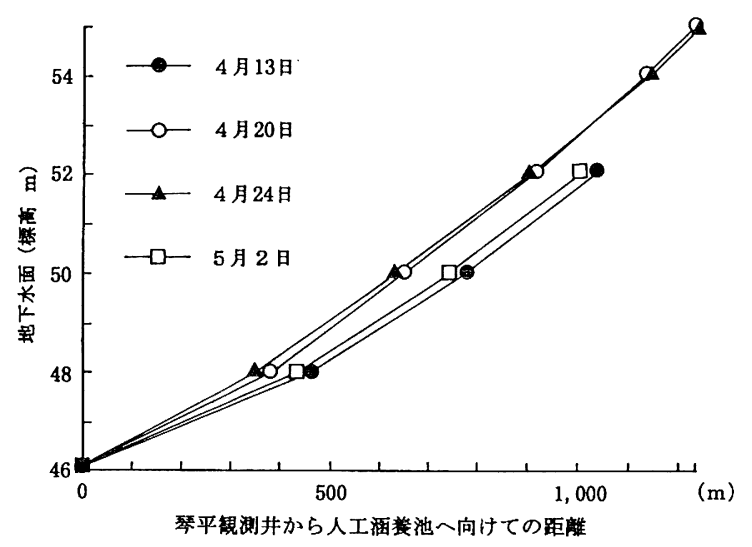

図 5 琴平観測井から婳養池の間の地下水面縦断面 の経時变化、1998年 4 月13日〜 5 月 2 日

Fig. 5 Changes of longitudinal profile of equipotential lines between the Kotohira observation well and the artificial recharge basin, April 13, May 2, 1998 (注：1. 図 4-1 〜 2 および測水の結果よ り作成。2, 琴平観測井、涵養池の位置 は、図 4-1〜2を参照。)

人工涵養の効果はこの一帯にまでは及んでいな wo

\subsection{5 地下水面の縦断面}

上の 4 回の時点 $(4-3-1 \sim 4)$ の地下水面図か ら琴平観測井と涵養池の間の地下水面の縦断面を 作成し、人工涵養に伴う、地下水面の経時変化を 追認した(図 5 )。

すなわち、給水を開始することにより、地下水 面は高まり、地下水堆の形成が認められる。時間 を置いて、地下水面の上昇は標高の低い位置に移 る。地下水面は、給水を停止した後、直ちにもと の高さには戻らない。

\section{4 婳養効果の及ぶ範囲}

今回の人工涵養実験の実施により、地下水位の 強化という点から涵養効果の及ぶ範囲はどのよう に設定されるのか。池の西方の一帯の範囲に限っ て言えば、結果として、涵養池よりその西方に向 けてほほ50m の等高線の位置までと設定してよい。 理由を挙げる。第 1 に、琴平観測井より東側、 涵養池までの地下水面は上昇した。第 2 に、平年 的には、琴平観測井の地点の水位は降下する時期

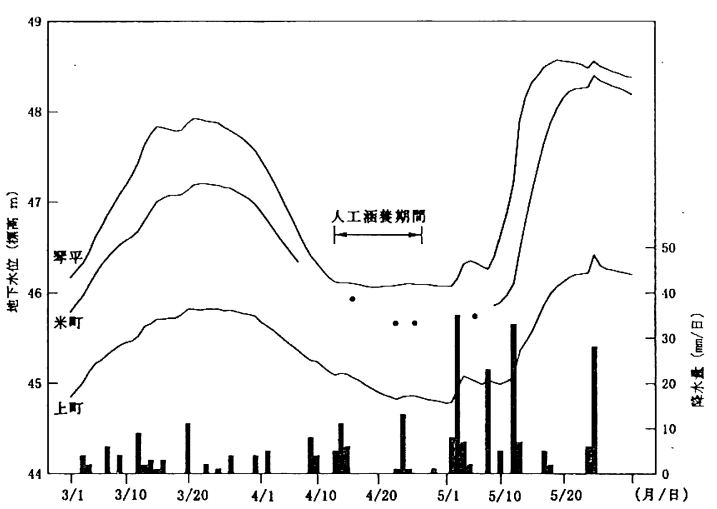

図 6 琴平、米町、上町の各観測井の地下水位の経 時変化、1998年 3 月 1 日〜 5 月31日

Fig. 6 Changes of ground water level at the Kotohira, Komemachi and Uemachi observasion wells, March 1, May 31, 1998 （注：1．各観測井の記録より作成。2，米 町観測井の 4 月 8 日〜 5 月 4 日は欠測。こ の間、測水によって得られた 4 回の水位を 黒丸で補った。3．降水量は、扇央部で測 定。位置は図 4-1 - 2 参照。)

であるにもかかわらず、涵養期間中、同地点の水 位は、降下することなく、ほぼ横ばいの状態を維 持した(図 6)。一方、市街地の中央部にある、米 町、上町の観測井地点の水位は、例年どおり低下 した(図 6)。両地点とも、涵養中に生じた地下水 の主要な流れの範囲から外れている。第 3 に、扇 端の標高45〜 50m の間は、湧泉帯にあたり、扇状 地の地下水は高水位の時期にあっても、この湧泉 帯において流出する5)。

\section{5. 結び}

秋田県六郷局状地において、融雪の終了後に現 れる一時的な地下水位の低下時に的を絞り、池底 の面積 $1,045 \mathrm{~m}^{2}$ の涵養池を用いて、地下水人工涵 養の実験を実施した。池への給水の期間は、1998 年 4 月13日 $(14: 00)$ から 4 月27日 $(14: 00)$ までの 14日間である。

実験の結果は、すでに述べたとおり、涵養池か らの浸透量、地下水堆の形成、地下水面を上昇さ せる範囲、さらに地下水面の低下を防ぐことので きる範囲の確認などの点において一定の成果をお さめることができた。 
今後は、旧河道の帯水層構造などを含めた扇状 地全般の水理特性に関する考察はもとより、今回 の成果を踏まえながら、さらに新たな実験を重ね、 源水の前処理、池を長期間にわたって使用する方 法、池の管理に要する費用などについて検討を加 える。最終的には、今回使用した池を、六郷扇状 地の地下水強化を図った実用的な涵養池として機 能させる。

謝辞：本研究は、六郷町の協力のもとで行って いる。また、人工涵養に着手した基礎は、文部省 科学研究費 (1991 -93年度、課題番号：03680207) および東北農政局 (計画部資源課) からの受託研究 (1993～95年度)などによるところが大きい。記し て関係機関と各位に深謝申し上げる。

\section{注}

1) 六郷町には、池 1 (1991年造成)、池 2 (1992年造成、 1996年拡張)があり、積雪時の地下水位の低下を防ぐ ために主に冬季間に稼働させる。これらの池を用い た人工涵養の実験結果については別の機会に取り上 げたい。

2) 今回の実験に際して、人工涵養の源水および実験に かかわる期間の地下水の水質分析は行わなかった。 なお、今回使用した排水路と同一の水路網の水の水 質分析は別の機会に行った(肥田、1990、p.171)。

3) 深度の異なるピエゾメー夕(最深100m)による観測に よると、六郷扇状地の帯水層に扔ける深度別の水理 ポテンシャル差は、涵養域である扇央において大き く、湧出域である扇端において小さい。

4）ピエゾメータの観測地に基づき、均一の带水層に あって深度と圧力水頭がどのように異なるのかにつ いての考察は別の機会にとり上げたい。

5) 扇端部にあって、湧泉帯よりも西側の地下水面は、 年間を通して湧泉帯の東側の地下水位の高低に大き く影響されない。

\section{参考文献}

太田由紀子(1997)：扇央から扇端間における地下水位 変動の相関一秋田県六郷扇状地を事例として一. 秋 大地理、44、15 20.
栗城 稔 (1997)：「雨水浸透と地下水涵養」6.人工

涵養の技術. 地下水学会誌、39-1、33 41.

建設省河川局河川計画課・編 (1988)：『地下水人工涵

養の現況と課題』山海堂、260p.

佐藤淳悦 (1998)：秋田県六郷扇状地における地下水位

と湧出量の年変化. 秋大地理、45、27 32.

全地対：全国地下水利用対策団体連合会 (1985)：山形

市の地下水保全への対応. 天の水地の水、73、33

36.

長瀬和雄 (1982)：秦野盆地の地下水と地下水の人工涵

養. 地下水と井戸とポンプ. 1987-12、18２5.

肥田 登 (1987)：秋田県六郷扇状地における池を用い

た浸透実験. 日本地下水学会誌、29-1、19２5.

肥田 登(1990)：『扇状地の地下水管理』古今書院、

263p.

肥田 登 (1994)：地下水人工涵養研究の展望. 『地下水

問題この 10 年とその将来展望』日本地下水学会 (編)、 $117 \sim 121$.

肥田 登(1997)：水循環と地下水人工涵養. 『シンポジ ウム水循環』講演要旨集、日本学術会議陸水研連 · 水資源研連、 $47 \sim 52$.

山本荘毅 (1958)：地下水の人工涵養. 水利科学、2-1、 $62 \sim 68$.

BMI: Bundesminister des Innern(1985) : Kïnstliche Grundwasseranreicherung. E. Schmidt, Berlin, 559s.

Hida, N.(1989) : Artificial recharge of ground water via paddy fields in an alluvial fan, Northern Japan. Johnson, A.I. and D.J. Finlyson(eds.): Artificial Recharge of Ground Water. ASCE, New York, 567-573.

Hiyama, T., K. Katsuragi, M. Suzuki and I. Shida (1989) : Experimental studies of artificial recharge of ground water in Yamagata City, Japan. Johnson, A.I. and D.J. Finlyson (eds.): Artificial Recharge of Ground Water. ASCE, New York, 574-581.

O'Hare, M.P., D.M. Fairchild, P.A. Hajali and L.W. Canter (1986): Artificial Recharge of Ground Water. Univ. of Oklahoma, 419p.

Schmidt, W.-D. (1994) : Stand der künstlichen Grundwasseranreicherung in Deutschland. gwf-Wasser/Abwasser, 135-5, 273-280.

（受付：1998年 7 月21日、受理：1998年11月27日） 